\title{
Emergences and Convergences .
}

\section{Susan Stanford Friedman}

\author{
There is no trouble about the art, it is the \\ appreciators we want. \\ H.D., Notes on Thought and Vision \\ She knew the battle. It was her career. \\ Rachel Blau Duplessis, "Family, Sexes, \\ Psyche"1
}

MLA CONVENTION HALLS burst with jostling crowds, people streaming out of elevators, into ballrooms, out of tiny rooms, confronting each other, stealing glances at badges, working to make a place for themselves in the profession, the procession of intellectuals. It hardly seems the place to have a thoughtful conversation about why we do the work that we do. But it happened. Skipping sessions, I sat down at a coffee-littered table with a friend, another woman who writes about H.D. The world of MLA ebbed into the background as talk flowed smoothly in and around H.D., our families, our desire to write, the hectic pace of our jobs, our overlapping research, and our experience of growing up or older in a profession caught in the processes of transformation. Newer to the world of H.D. than I, my friend asked me what it had been like working on H.D. for so many years. Why did I choose H.D.? What has she meant for my life? How does it feel to have labored essentially alone for so long, then to be surrounded by so many others in the midst of an H.D. revival and serious reassessment of her achievement? She wanted me to talk, but more than that she wanted me to write it down. A document. For the record. Did she realize "how frail the cord was, how heavy the memories strung along the frail spider-web of a silver-cord that might so soon be broken"?2

These questions seem natural enough for today, when a whole generation of feminist critics have broken so many personal silences. But I am deeply aware that the answers, even the questions themselves, go against the scholarly tradition in which I was trained and by which I am still frequently judged. Scholarship, I was taught, requires a dispassionate choice of subject, a rational discourse of objectivity, an individual search for in- 
tellectual originality, an authoritative voice claiming a "science" of creativity. Of course, in 1965 when I entered graduate school, such scholarly objectives were personally charged for me right from the beginning, though I scarcely understood why. I enthusiastically went to graduate school simply because I loved literature-fantasy, language, the great themes of life and death, quest and revelation. With a few exceptions, graduate school was a slap of cold water on such unseemly enthusiasms. What I didn't understand at the time was that even the intellectually challenging professors held out an ideal of detached objectivity that was culturally associated with the masculine. Taught to repress the qualities traditionally connected with the feminine, or at least to banish them from the public marketplace of ideas, I was caught in the double bind of the woman critic. Excitement was acceptable, within the prescribed channels of pure intellect. The personal was irrelevant. Commitment signified bias. Passion was inadmissable.

Perhaps this is why I was subconsciously drawn to H.D.'s story of the confrontation between Mary of Magdala and Kaspar-Mary, whose scarf slipped to the floor, loosing a shimmer of hair that deeply disturbed the Mage, who was not nearly so wise as he seemed:

it was unseemly that a woman appear disordered, dishevelled;

it was unseemly that a woman appear at all. ${ }^{3}$

For both the women and men of my generation, as well as today, I suspect that the personal was deeply relevant to the choices we made as scholars. But we often masked those personal determinants from ourselves and each other, systematically wiping all such traces off the rational surface of our work just as we learned to delete the pronoun "I" in favor of the impersonal "we" or the omniscient authoritative persona.

Why did I choose H.D. for my dissertation in 1968? Trilogy was the first H.D. poem I ever read. L.S. Dembo taught it alongside the neo-epics of the more famous modernist men, and I naively plunged into Helen in Egypt for my seminar paper. I had scarcely heard of imagism, and I was delighted to see that I had very few articles to read for my paper because 
there was almost no scholarly literature on her post-imagist poetry. Consciously, I reasoned that by working on H.D., I could engage directly with literature, without the mediation of professionalism - the shelves of critical books that would await research on Virginia Woolf, my other choice. I had been a Greek major at Swarthmore College. Gods and goddesses, fables and fairy tales, had been the staple of my reading for many years. Surely I could think of something original to say. I also knew that I was at home in H.D.'s long poems - I found them magical and easy, especially compared to the allusive puzzles of Pound's Cantos, which left me feeling confused and uneducated. Helen invited me: into its clear liquid surfaces and visionary depths.

I did not consciously understand that H.D. perfectly addressed my alienation as a woman graduate student. By pioneering the study of her epic poems, I could avoid the professionalism that deadened my joy in literature. More fundamentally, by reading a woman poet, I was unknowingly undermining the patriarchal basis of my formal education. The only women writers taught in my college and graduate school courses were Emily Dickinson, Virginia Woolf, and H.D. Not even the nineteenthcentury giants of women's literature-Jane Austen, George Eliot, the Brontë sisters-appeared in courses or examinations, let alone the vast numbers of women writers who deserved representation in the curriculum. The literary canon was male, my teachers were male, and the scholarly tradition to which I had applied for admission was masculine. I didn't even know I resented it. But I chose H.D.

I didn't know just how rebellious that choice was. My rebellions seemed focused in other directions: the anti-war movement, the civil rights movement, the educational reform movement, and increasingly the fledgling women's movement. I lived a split life as a community activist and researcher, complicated by being a mother and wife as well. I bounced back and forth between a library carrel, a demonstration, a new baby, a political meeting, a consciousness raising group, a party as a faculty wife - without the least idea of how to integrate these different public and private selves.

Writing a dissertation on H.D. didn't turn out to be straightforward. I had planned a brief introduction on Tribute to Freud as a key to the later poems. But when Norman Holmes Pearson kindly turned me loose in his collection of H.D.'s library and gave me copies of her unpublished long poems, my simple plans dissolved. H.D.'s own vast reading drew me out 
of pure literary research into the interdisciplinary task of learning what she had learned because of its importance to the cosmic vision in her epicsparticularly in the fields of psychoanalysis and hermetic tradition. Unable to rely on the familiar dissertator's crutch of explication de texte, it took me one whole semester to write the first seventeen pages of my dissertation. Instead of analyzing poetry, I found myself charting the debate between H.D. and Freud, the "argument that was implicit in our very bones," as she wrote. ${ }^{4}$

Deeply influenced by Dembo's Conceptions of Reality in Modern American Poetry, I began to apply his questions of epistemology to the issue of H.D.'s debate with Freud on the hunch that her divergence on concepts of perception, reality, and time would provide an approach to Trilogy and Helen in Egypt. ${ }^{5}$ At the same time, I was involved in a collective feminist project investigating psychological services for women, for which five other women and I did extensive interviewing, discussed, and jointly wrote chapters that eventually became $A$ Woman's Guide to Therapy. ${ }^{6}$ While calmly writing about Freud's materialist bias for my dissertation during the day, I was angrily writing about his androcentric bias and its destructive impact on women by night. The two projects seemed unrelated, written in different voices for different purposes. This split, this double consciousness, characterized many of the academic women of my generation - as if we had two brains, as if we were bilingual, as if a chasm separated the two sides of our public selves, the one side conventionally trained, the other side more volatile and rebellious. As Sheila Rowbotham wrote, "But always we were split in two, straddling silence, not sure where we would begin to find ourselves or one another. . . . A new consciousness is a laborious thing. Now we are like babes thrashing around in darkness and unexplored space. . .."7

The emergence of feminism in the Modern Language Association established a pathway through the institutions of knowledge where this split could be healed in the birth of a new consciousness, a new way of seeing, a new set of questions. The "unexplored space" was the representation of woman in men's writing and the tradition of women's literature itself. The work of women like Mary Ellmann, Florence Howe, and Kate Millett led the way into that space. Within the very halls of the professionalism from which I was so alienated, I heard two electrifying talks that gave me a sense of direction in my work on H.D. and a sense of purpose in be- 
ing a literary critic. One was by Adrienne Rich, "When We Dead Awaken: Writing as Re-Vision." The other was "Silences: When Women Don't Write," by Tillie Olsen. ${ }^{8}$ I remember particularly watching Rich's weary face and halting walk as she made her way to the large podium above which she was scarcely visible. Then her powerful voice vitalized her tired body as she broke through the traditional barriers of detached discourse to deliver a speech on women and creativity that was both private and public, both emotional and intellectual, both angry and rational, both political and academic.

Women's Studies as the academic arm of the women's movement spontaneously sprang up on campuses throughout the country in the early seventies as women realized that there was a way to integrate our feminist activism with our intellectual work. My dissertation, limping along through chapters on H.D.'s epistemology and history, took on energy from the movement. I began to realize that I was not simply an isolated scholar but part of a community engaged in a project of discovery with vast political implications for women. Instead of avoiding all criticism, I began to read it avidly, especially those early books and articles which established a tradition of women's writing. I could see that my work on H.D. was part of a larger project of discovery, by now the most familiar and well articulated aspect of feminist criticism: finding the lost and forgotten women writers of the past. A communal awareness spread rapidly through the convention halls and pages of journals open to feminist criticism. As Sandra Gilbert and Susan Gubar have written, women writers were like the submerged continent of Atlantis. ${ }^{9}$ Like the deep-sea diver in Rich's "Diving into the Wreck," feminist critics were archaeologists digging through rubble to restore what had been lost. Literally and figuratively, I had gone through the bowels of the university library where the books slated for eventual abandonment were stored to find copies of H.D.'s volumes, their dusty covers undisturbed for decades:

for they remember, they remember, as they sway and hover, what once was - they remember, they remember-

they will not swerve - they have known bliss, the fruit that satisfies - they have come back. ${ }^{10}$ 
I was excited. I sensed an audience, a community, a mission. But I was on the defensive. In job interviews or casual conversations about work, I kept hearing "Who did you say you're working on? H.D.? Who's he?" An advisor angrily challenged my drafted chapters on the debate between H.D. and Freud: “How can you come out on H.D.'s side like this? When you put a genius like Freud on a scale beside a silly woman, how can you possibly identify with her?" There were other challenges: "You've got a husband. You don't need a job like our other students." "Now that you're pregnant, I don't know if I can support you as strongly as I did before. I will have to wait and see whether you are still committed to the field." "I need an assurance from you before the department can support your job applications that you will accept any job you are offered." "Do you really think this minor poet is worth a dissertation?"

These challenges were painful, but they made me think. For a whole generation of young feminist scholars, the very marginality of our work, the very precariousness of our position within the profession, generated a series of questions about the writers on whom we worked. Why was it necessary to re-cover and re-member women writers? Had they been covered over, dis-membered? By whom? Why? The critical perspectives in which we had been trained, especially New Criticism, had no answers for such questions. Writing about women writers is not the same as writing about male writers. Research on women is not necessarily feminist research on women. We can't, Charlotte Bunch said, simply add women to the pot of knowledge and stir. ${ }^{11}$ Add women to the soup, and the flavor changes; indeed the very pot itself, the very paradigms of knowledge, must change. The very loss or distortion of women writers in traditional critical discourses generated a new critical paradigm for the study of women and writing, one whose categories come from an integration of feminist theory and praxis with literary studies.

In 1973, just as I was finishing my dissertation, I wrote "Who Buried H.D.: A Poet, Her Critics, and 'The Literary Tradition," "an essay that attempted to turn the defensive stance imposed on me into a genuine apologia, that is, a defense of H.D. and the issues her case raised. ${ }^{12}$ I wanted to show how the double standard of criticism identified by critics like Ellmann and Elaine Showalter had worked in the specific case of H.D., how the literary canon is built on unstated phallic premises that inherently exclude or trivialize women, how such biases lead to a systematic mis- 
reading of women's texts. Although I patched pieces of this essay into odd corners of my dissertation, it didn't fully belong. My thesis showed all the strains of the "double consciousness" Rowbotham described, the split mind-set that feminist scholars have had to learn to transcend. There were eight chapters in which the issue of gender never appeared, and there was one ghettoized chapter on H.D. as a woman in debate with Freud. I did not know how to integrate questions of sexual difference, gender, and androcentric canon formation into a general study of H.D. I was two voices - the old and the new, the male-trained and the feminist - who didn't know how to talk to each other.

What I needed to learn was to un-learn. To re-member, I had to dismember and mis-read. Feminist criticism begins in negation. The garment of knowledge is mis-sewn; its seams must be torn, thread by thread, before it can be refashioned. The scene of my un-learning was not a quiet engagement with H.D.'s poetry in the privacy of a study. Instead, I found the theoretical basis for my research first in teaching Open Admissions students at Brooklyn College, which led me to sustained analysis of the racial structures of the literary canon, and then teaching Women's Studies students at the University of Wisconsin, which led to a systematic, interdisciplinary analysis of women and culture. For Women's Studies, I developed a humanities course titled "The Meanings of Woman in Western Culture," an interdisciplinary introduction to Women's Studies which examines the cultural production of woman's nature and the impact of those representations on women's lives. This immersion in patriarchal constructs before two hundred non-feminist students every year fed back into my work on H.D. Teaching taught me how to integrate the feminist and non-feminist voices I heard within. The point of the course is "re-vision," as Rich has defined it:

Re-vision - the act of looking back, of seeing with fresh eyes, of entering an old text from a new critical direction - is for women more than a chapter in cultural history: it is an act of survival. Until we can understand the assumptions in which we are drenched we cannot know ourselves. And this drive to self-knowledge, for women is more than a search for identity: it is part of our refusal of the selfdestructiveness of male-dominated society. . . . We need to know the writing of the past, and know it differently than we have ever known it; not to pass on a tradition but to break its hold over us. ${ }^{13}$ 
The first few times I taught the course, my students were both enthralled and rebellious as they experienced both despair and exhilaration, disorientation and validation, hurt and anger. In my efforts to uncover the pervasive androcentrism of western culture, I had unwittingly discussed only women's victimization, silence, invisibility. Their demands for more hopeful material, for novels that didn't end in women's suicide or madness, forced me to look for what I had forgotten to see - that women have survived, spoken, made themselves visible, sometimes anxiously as Gilbert and Gubar have written, and sometimes more joyously as a display of women's quilts eloquently testifies. Encoded in the speech of that survival is the struggle, what Rachel Blau DuPlessis calls "the career of that struggle." "The revolutionary," Sheila Rowbotham wrote, "must listen very carefully to the language of silence." ${ }^{14}$ Culture, I would add, is never hegemonic, monolithic, static, but always polyvocal and dynamic. As an oppressed, repressed, suppressed group (take your theoretical pick), women have always found ways to subvert, transform, appropriate, negotiate, erupt, disrupt. Learning to un-do the institutions of knowledge, in other words, leads ultimately into a process of re-doing. First deconstruct, then re-construct the world of letters. Like Christine de Pizan in The Book of the City of Ladies. At the beginning, she sits in her study, reading all the things men have said about women, feeling sicker and sicker until her mother's call to dinner breaks across the process of male sentencing. Then, the "ladies" of her vision appear, projections of her own voice, to show her how to re-build the city of women. ${ }^{15}$

This line of thinking changed the way I read H.D. in the mid-seventies. It was not that I had viewed her as a victim. I had always seen her as a woman who forged her unique vision by disagreeing with the authorities whom she most reverenced. But teaching Women's Studies led me to see how the issue of gender pervaded that dialectical process. Her authorities were all male, indeed emblems of patriarchal thought in aesthetics, religion, and psychology. Increasingly, I came to see her work as an enactment of the very dilemma of women's existence in patriarchy. Her debate with Freud, her transformations of Judeo-Christian tradition, and her entangled relations with Pound, Aldington, and Lawrence embodied a paradigmatic confrontation with man's artistic, erotic, religious, and scientific power. Like my students, I asked, how did she survive? What was the source of her empowerment? 
The answer, I believed, lay in her creation of a revisionary mythos founded in her poetic resurrection of the primal mother as both psychic and mythic spirit. "The mother is the Muse, the Creator," she wrote. ${ }^{16}$ The essays I wrote on H.D.'s revisionist epics from 1976 to 1979 led ultimately to Psyche Reborm: The Emergence of H.D., with its underlying theme of women's survival through a dialectical transformation of patriarchal culture. ${ }^{17}$ The eroticism of the daughter's bond with the mother, identified but not much explored in Psyche Reborn, led further to questions of the relationship between sexuality and textuality, between erotics and poetics, between gender and culture which have been the preoccupations of my work on women writers since I finished the book.

Unlike a child, a book delivered drops into a void. It doesn't need you any more. You wait. You wonder if it exists. It is both you and not-you, a forever fixed extension of your passionate labor, but cut off from your continuing evolution. Every once in a while, a letter comes, or a reviewbut no matter what the words say, they can never quite match the outpouring of energy and the residue of emptiness. I think of Lucille Clifton's poem about birthing:

... her bars lie wet, open

and empty and she has made herself again

out of flesh out of dictionaries,

she is always emptying and it is all

the same wound the same blood the same breaking. ${ }^{18}$

Gradually, however, it sinks in. Some people did read the book. Some people felt changed by the book. Some people even said the book gave them an H.D. they had always known but never articulated, or an H.D. they had been denied by more conventional readings, or an H.D. they could now approach for their own reconstitutive process. The letters I received from poets moved me the most, especially when they came with the poems that testified to H.D.'s continuing existence in the generational processus of poets. I felt she had emerged, out of the cocoon of history.

In a much more modest way, so had I. Publishing the book was a public act, a coming out of the closet, the unseemly speech of a woman about a woman from a woman's point of view. I was female, my subject was female, my editor was female, her reader was female-almost too many fe- 
males for my department. Almost, I lost my job. Just one vote less, and I would have been in the courts. I had never even looked at any of the articles I had published. But I set the book with its haunting photo and hidden golden cat on the mantlepiece for awhile, greeting it with a glance now and then as I walked by.

Woven as she was into my own life, the career of my struggles as a woman, is it any wonder that the H.D. I have written into being reflects my needs and desires? No. "My H.D. isn't your H.D.," Barbara Guest warned me before beautifully inscribing a copy of her book for me. Or perhaps I said it to her. I don't remember now who said it to whom. But meeting as we often did at the Beinecke Library, sharing our frustrations, supporting each other's efforts, I think we both knew that the H.D. we were each constructing for ourselves and our readers was different:

but my mind (yours)

has its peculiar ego-centric

personal approach

to the eternal realities,

and differs from every other

in minute particulars,

as the vein-paths on any leaf

differ from those of every other leaf

in the forest, as every snow-flake

has its particular star, coral or prism shape. ${ }^{19}$

Writing a biography is a fictional act. Writing a critical study is also a fictional act. The poet and the poem are incomplete until they are "read." A "reading" completes the words on the page, the fragments of a life, but any such reading has too much of the reader in it to be "definitive," "objective," the "truth." We had better "read" the biographer, the critic, if we want to "read" the life and work they recreate.

There is something in me that resists being read as I would read others. I want to choose the scenes of my own disclosure. Writing criticism allows 
me to screen the personal, to displace the private rhythms of intellectual desire onto the public text of scholarship. Is this dishonest? I don't think so. But it may be less brave than being a poet. For all the genuine embattlement of our lives, I think feminist critics do not have the same courage as the poet. Perhaps, however, we could never survive in the realm of intellectual male discourses if we didn't wear some protective coloration, the camouflage of detachment.

This protection, however, is not simply a mask; it is also part of the process of scholarship. The choice of a subject and the re-construction of a poet in a critical study are personally determined and subjective acts, I believe. But these activities are not solipsistic. Nor are all the reconstructions of H.D. equally true (or untrue). Writing about the life and work of a poet involves a constant exchange with the language of an other, with the linguistic traces of another person who had (or has) her own voice, subjectivity, existence. For me, the challenge of criticism centers in that exchange-my attempt to hear the autonomous, pre-existing voice of the poet when I know that all I have to go on are words, when I know full well that my own subjective lens shapes what and how I read. A friend who is an historian calls this process "dialoguing with the data," a startling personification of words that nonetheless captures the give-and-take of working with documents. Perhaps my desire to overhear the poet who had (and has) a being independent of my reconstruction of her is what led me into the archives. Diaries, letters, unpublished manuscripts - the vast and overwhelming traces of H.D. stored in the Beinecke Library-provide a foundation that supports her public works, a basis against which I have continually checked my readings in the attempt to prevent sheer solipsistic recreations.

The voice of H.D.'s daughter, Perdita Schaffner, has also been an important check, an authority whose very subjectivity brilliantly illuminates the mother. "She was intensely maternal," the daughter wrote of her mother, "- on an esoteric plane. She venerated the concept of motherhood, but was unprepared for its disruptions." 20 More simply and without bitterness, she told me at our first meeting in 1978, "my mother never stood in the kitchen and made peanut butter sandwiches for me. She never had a single child come to the house for me to play with." I was startled. For my own two young children, I had made endless sandwiches; I was constantly on the search for playmates. A gulf opened between me and the 
poet with whom I had so deeply identified (and still do). I have been haunted by that image - the empty spot in the kitchen where H.D. never stood in front of the peanut butter jar. The H.D. who never made peanut butter sandwiches is missing from Psyche Reborn. Something of the dailiness of H.D. is absent from my portrait of the poet-prophet. Something as well of the contradictions out of which her poetry sprang. It is from the daughter, who has far more reason than I to be entangled in subjectivity, that I have seen an image of H.D. in which the complex interplay of the personal and the public, the mundane and the visionary, the woman and the poet is most vividly present.

This was new. Reading others reading H.D. altered my reading of H.D. For so many years, I had worked in isolation, most often refusing the interpretations of others, defining my own position through the negation of others. The pieces of Robert Duncan's monumental H.D. Book, appearing in fragments in various little magazines for many years, was of course an exception. As Rachel Blau DuPlessis has said, Duncan's book invents an essay voice that allows him to explore H.D.'s significance, his own poetic, and the meanings of modernism in poetry. ${ }^{21}$ But the very fact that these brilliant insights into H.D. came from a poet, not a critic, had emphasized my isolation as a critic. By the late seventies, however, I was hearing not only Perdita Schaffner, but also other feminist critics who were beginning to write about H.D. Instead of the defensive posture I had assumed, I could experience the exhilaration of listening to others. DuPlessis, with her brilliant reading of H.D.'s narrative strategies in Helen in Egypt, blew me away one MLA. Susan Gubar, with her resonant reading of H.D.'s echoing spells in The Hedgehog and Trilogy, tied H.D. into the mainstream of her pathbreaking work with Sandra Gilbert on the female literary tradition. ${ }^{22}$ Learning from others about H.D. took some of the pressure off me-the insistent need to convince others that H.D. must be read, must be understood as a major voice in the twentieth century. It still hurts when critics say to me, "You know, I admire your work, BUT . . . I just don't like her poetry. . . ." It hurts because the identification with H.D. that fed Psyche Reborn still runs deep-a rejection of H.D. must be a rejection of me. Rejection immobilizes, paralyzes.

But because there is a whole chorus of voices now - feminist and nonfeminist - all reading and writing about H.D. in ways utterly different from mine, the pressure is off. I feel I have succeeded at what I had at- 
tempted - to bring H.D. back into the public domain of letters so that she could be read from all the perspectives her richly complex work deserves.

The first work I did on H.D. after I finished Psyche Reborn is symbolic of this collaborative community of disparate voices. Rachel DuPlessis and I, while both in the throes of our struggles for job security, decided to jointly author some articles on H.D., each bringing the ideas we had individually developed into a communal text. Take two utterly different women, with different strengths, weaknesses, and styles. Put them in a pot and stir. The soup can come out tasty or tasteless. I think it came out enriched. Others can judge (and have judged) what we wrote together. ${ }^{23}$ But there is another kind of enrichment evident in the process of collaboration itself, one that has been present in the evolution of feminist criticism since its beginnings. I refer to a continued anarchistic current of resistance in feminist criticism to individual authorities and discipleship, a kind of insistence on the collaborative and collective nature of the scholarly enterprise. "Call me Mary Seton, Mary Beton, Mary Carmichael or any name you wish," wrote Virginia Woolf, the mother of twentieth-century feminist criticism in denying her own authorial "I" to insist on the collective authority of many voices - the "we" of women's experience. ${ }^{24}$

Susan Gubar once said that it was particularly fascinating to watch what has happened to the reputation of H.D. over the last twenty years because her story highlights the process and politics of literary canonization. I think she was right. ${ }^{25}$ Take the personal story of any feminist critic, and I think that story would also illuminate some aspect of women's advance into the forbidden and forbidding territories of male discourses:

we are voyagers, discoverers

of the not-known,

the unrecorded;

we have no map;

possibly we will reach haven, heaven. ${ }^{26}$ 
1. Epigraphs are from H.D., Notes on Thought and Vision \& The Wise Sappho (San Francisco: City Lights Books, 1982), p. 26; Rachel Blau DuPlessis, "Family, Sexes, Psyche: An Essay on H.D. and the Muse of the Woman Writer" (1979), reprinted in Michael King, ed. H.D.: Woman and Poet (Orono, ME: National Poetry Foundation, 1986).

2. H.D., Bid Me to Live (A Madrigal) (1960; rpt. New York: Dial Press, 1983), p. 25.

3. H.D., Trilogy (New York: New Directions, 1973), p. 137.

4. H.D., Tribute to Freud (1956; rpt. Boston: David R. Godine, 1974), p. 13.

5. L.S. Dembo, Conceptions of Reality in Modern American Poetry (Berkeley: University of California Press, 1966). Can we ever find the way to fully credit what our most important teachers have given us?

6. Susan Stanford Friedman, with co-authors Linda Gams, Nancy Gottlieb, and Cindy Nesselson, $A$ Woman's Guide to Therapy (Englewood Cliffs, NJ: Prentice Hall, 1979).

7. Sheila Rowbotham, Woman's Consciousness, Man's World (London: Penguin, 1973), pp. 31, 28.

8. Adrienne Rich, "When We Dead Awaken: Writing as Re-Vision" (1971), in On Lies, Secrets, and Silence: Selected Prose, 1966-1978 (New York: Norton, 1979), pp. 33-50. Tillie Olsen, "Silences: When Women Don't Write" (1971), incorporated into Silences (New York: Delta, 1972).

9. Sandra M. Gilbert and Susan Gubar, Madwoman in the Attic: The Woman Writer and the Nineteenth-Century Literary Imagination (New Haven: Yale University Press, 1979), pp. $99-100$.

10. H.D., Trilogy, p. 119.

11. Charlotte Bunch, "Visions and Revisions: Women and the Power to Change," a paper delivered at the National Women's Studies Association Convention in June, 1979, excerpted in Women's Studies Newsletter 7 (Summer 1979), pp. 20-21. For other discussions of the paradigm shift involved in feminist scholarship, see Sandra Coyner, "Women's Studies as an Academic Discipline: Why and How to Do It" and other essays in Gloria Bowles and Renate Duelli-Klein, eds. Theories of Women's Studies $(1980,1981$, rpt. London: Methuen, 1984).

12. Susan Friedman, "Who Buried H.D.? A Poet, Her Critics, and 'The Literary Tradition,' " College English 36, no. 7 (March 1975), pp. 801-14. The essay was first delivered as a paper at MMLA in 1973.

13. Rich, "When We Dead Awaken," in On Lies, p. 35.

14. DuPlessis, "Family, Sexes, Psyche," p. 145; Rowbotham, Women's Consciousness, p. 30.

15. Christine de Pizan, The Book of the City of Ladies, trans. Earl Jeffrey Richards (New York: Persea Books, 1982), pp. 3-8. 
16. H.D., End to Torment (New York: New Directions, 1979), p. 41.

17. See Susan Stanford Friedman, “Creating a Woman's Mythology: H.D.'s Helen in Egypt," Women's Studies 5, no. 2 (1977), pp. 163-98; "Psyche Reborn: Tradition, Revision, and the Goddess as Mother-Symbol in H.D.'s Epic Poetry," Women's Studies 6, no. 2 (1979), pp. 147-60; Psyche Reborn: The Emergence of H.D. (Bloomington: Indiana University Press, 1981).

18. Lucille Clifton, An Ordinary Woman (New York: Random House, 1974), p. 50.

19. H.D., Trilogy, pp. 51-52.

20. Perdita Schaffner, "The Egyptian Cat," in H.D., Hedylus (Redding Ridge, CT: Black Swan Books, 1980), p. 143. For Schaffner's other extraordinary sketches, see "Pandora's Box," in H.D., HER mione (New York: New Directions, 1981), pp. vii-xi; "Unless a Bomb Falls. . .," in H.D., The Gift (New York: New Directions, 1984), pp. ixxv; "A Profound Animal," in H.D., Bid Me to Live (A Madrigal) (Redding Ridge, CT: Black Swan Books, 1983), pp. 185-94; “Merano, 1962," Paideuma 4 (Fall/Winter 1975), 513-18.

21. Some seventeen installments of the brilliant H.D. Book have appeared from 1963 to 1985. The most recent is "From the H.D. Book, Part II, Chapter 5," Sagetrieb 4, no. 2/3 (Fall/Winter 1985), pp. 39-86. See also Origin (July 1963), Coyote's Journal (1966 and 1967), Caterpillar (October 1967 and January 1968), TriQuarterly (Spring 1968), Stony Brook Review (Fall 1968), Sumac (Fall 1968), Caterpillar (January 1969 and April 1969), Io (Summer 1969), Stony Brook Review (Fall 1969), Io (1971), Credences (August 1975), Chicago Review (Winter 1979), Montemora (1981). DuPlessis' comments about the innovative voice of the H.D. Book were made in a letter to me, 12 January 1986.

22. See Rachel Blau DuPlessis, "Romantic Thralldom in H.D.," Contemporary Literature 20, no. 2 (Summer 1979), pp. 178-203; Susan Gubar, "The Echoing Spell of H.D.'s Trilogy," Contemporary Literature 19, no. 2 (Spring 1978), pp. 196-218. Their later work on H.D. has continued to be critical to the development of H.D. criticism. See DuPlessis, Writing Beyond the Ending: Narrative Strategies of Twentieth-Century Women Writers (Bloomington: Indiana University Press, 1985), pp. 66-83, 116-21, and H.D.: The Career of That Struggle (Brighton: Harvester, 1986); Gubar, "Sappistries," Signs 10 (Autumn 1984), pp. 43-62.

23. See, for example, Claire Buck, "Freud and H.D. - bisexuality and a feminine discourse," $M / F 8$ (1983), pp. 53-65.

24. Virginia Woolf, A Room of One's Own (1929; rpt. New York: Harcourt Brace Jovanovich, 1957), pp. 4-5.

25. Susan Gubar, remarks made as a discussant, MLA, 1983.

26. H.D., Trilogy, p. 59. 